\begin{tabular}{|c|c|}
\hline \multirow{3}{*}{ 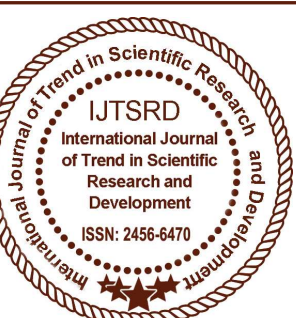 } & $\begin{array}{l}\text { International Journal of Trend in Scientific } \\
\text { Research and Development (IJTSRD) }\end{array}$ \\
\hline & International Open Access Journal \\
\hline & ISSN No: 2456 - 6470 | www.ijtsrd.com | Volume - 2 | Issue - 1 \\
\hline
\end{tabular}

\title{
Case Study of Flood Risk Evaluation in Surat City
}

\author{
Parth Desani \\ PG Student (M.Plan), APIED, \\ V.V.Nagar, Gujarat, India
}

\author{
Dr. Neha Bansal \\ Professor, APIED, V.V.Nagar, \\ Gujarat, India
}

\begin{abstract}
There are many ways a disaster come and create huge damages to human surroundings. Flood is one of them. But for the flood it can be said that flood is a horrible disaster which affect many of human beings, animals and properties. Till day many floods came to the all over world. In India also many flood came and created huge disturbances to humanitarians and flood came in 2006 August in Surat city of Gujarat is one of heavy floods in India. Flood in Surat came in August of 2006 and left a huge mark in history of Surat. In this article, it is been studied that how flood occurred in city, what actions city commission took during and after flood and how flood risk evaluation were been done.
\end{abstract}

\section{Introduction}

An overflow of a large amount of water beyond its normal limits, especially over what is normally dry land.

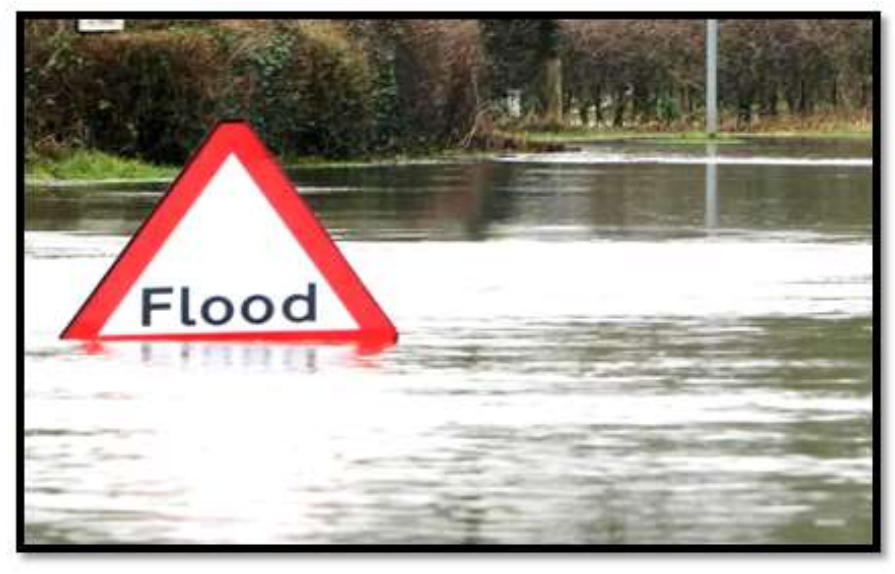

Fig. 1 Flood

Flooding may occur as an overflow of water from water bodies, such as a river, lake, or ocean, in which the water overtops or breaks levees, resulting in some of that water escaping its usual boundaries, or it may occur due to an accumulation of rainwater on saturated ground in an area flood.

\section{Study Area}

Surat is the eighth most populous city in India $(44,67,797)$. It is a large city beside the Tapi River in the west Indian state of Gujarat. Once known for silk weaving, Surat remains a commercial center for textiles, and the New Textile Market area is lined with fabric shop. Overlooking the river, Surat castle was built in the 1500 to defend the city against Portuguese colonists. Nearby, the Dutch, Armenian and English cemeteries contain elaborate colonial-era tombs.

\section{Past Floods in Surat}

In 1968 flood most of the city were under water due to flood and in 1998, around 30\% of city flooded due to release of water from Ukai dam located $90 \mathrm{~km}$ from Surat.

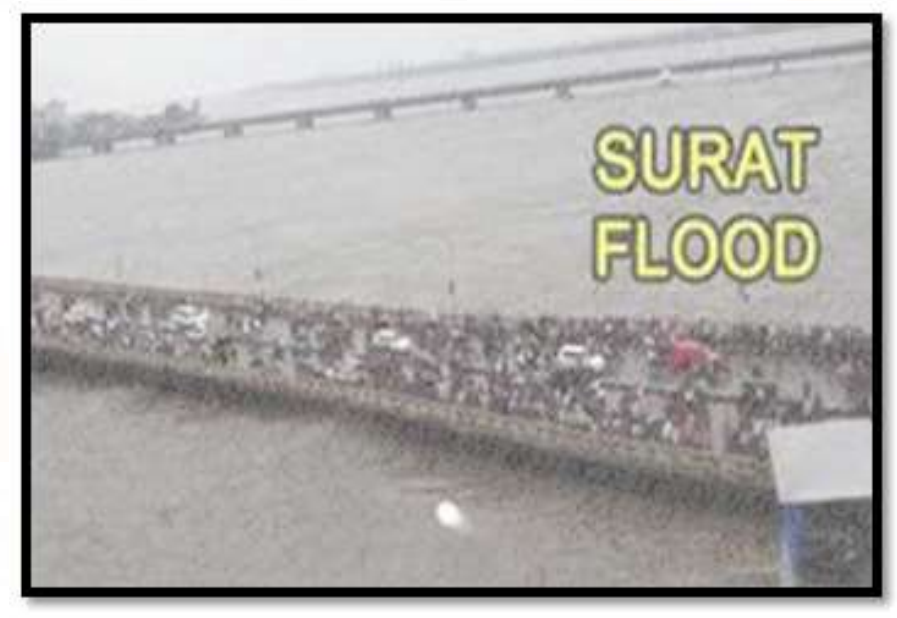

Fig. 2 Flooding in Surat 
After the 1998 floods, which had ravaged Surat, expert had discussed the problem thoroughly and presented many solutions. However, the government has not implemented a "single solution so far", Satyakam Joshi of city based Center of Social Studies said.

"The issues like precise monitoring of level of Ukai dam and timely release of water from the dam during monsoon, de-silting of river bed to increase the carrying capacity of river, issue of removal of encroachment on the river bed were left high and dry which has resulted in flooding of Surat city this year", Joshi said.

An expert on Ukai dam who has studied the dam and flooding in Tapi for 20 years I M Desai said it is not impossible to manage the waters in Tapi in a way that it would not flood Surat and proper monitoring and management could save Surat from such a disaster.

Speaking about long-term solution to avert recurrence of floods in the river Tapi, Desai suggested monitoring from the time of development of weather system which can cause heavy rains in Maharashtra and Madhya Pradesh via satellite pictures, inter-state cooperation cell should be formed to exchange exact figures of rains in those states and amount of water released from dams and proper management of water from Ukai dam to avert future floods.

\section{2006 Flood in Surat}

India - Walk around Surat, the diamond capital of India, and it is impossible not to notice "HFL 8/8/2006" scrawled on many walls. The inscription stands for "high flood level", where rising waters peaked on August 8, 2006 during a devastating flood.

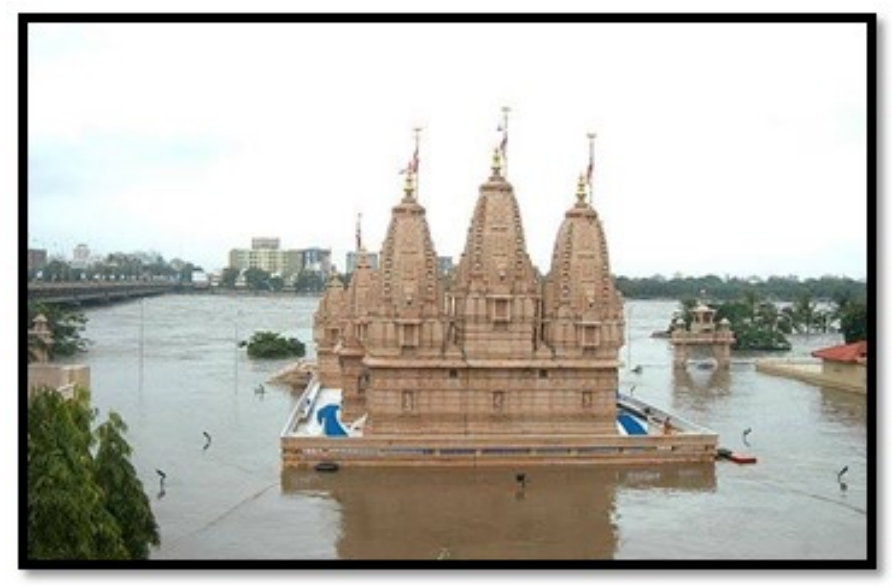

Fig. 3 Flood in Surat in 2006
Flooding is nothing new in Surat, a city of 5 million situated along the Tapi River on the west coast of India. In the past 100 years, Surat has experienced about 20 floods. But the 2006 flood was unusually destructive, killing more than 120 people, stranding tens of thousands in their homes without food or electricity and closing businesses and schools for weeks.

The Opposition Congress has alleged that the Surat flood this year was a man-made disaster and could have been averted had the state irrigation department officials not committed "criminal negligence". In a reply to opposition allegations the state government has formed a two-member inquiry commission to probe the exact cause of flood.

\section{Improving Coordination}

Akash Acharya, an academic working in the Centre of Social Studies in Surat who co-authored "Surat 2006 Floods: A Citizens' Report", has vivid memories of devastation. Yet today, Acharya, like many others in the city, feels that Surat is more prepared now than ever to deal with flooding. Thanks to a number of recent initiatives - and new protocols at the dam heavy rains in the past few years have not brought the usual inundations. It's similar story to how the city bounced back from a horrific plague in 1994 and emerged as a public-health model. With flooding, Surat decided it would not allow itself to become a disaster statistic once again.

How that happened is a story of partnership and will power. Many groups came together - local business associations, notably the Southern Gujarat Chamber of Commerce; TARU leading Edge, a well-known Indian consulting firm; the Surat Municipal Corporation and other government bodies; and the United States based Rockefeller Foundation. The partnership led to the formation of the Surat Climate Change Trust, which played an important role in setting up a comprehensive early-warning system for flooding in the city.

These systems are part of Surat's broader resilience strategy. The secretary of the Climate Change Trust, Kamlesh Yagnik, was also appointed Surat's Chief Resilience Officer. This is a post created to help Surat prepare for, survive and recover from all kinds of environmental, economic and social shocks - not only the usual floods and storms but also traffic congestion, air pollution, water scarcity and social 
cohesion.

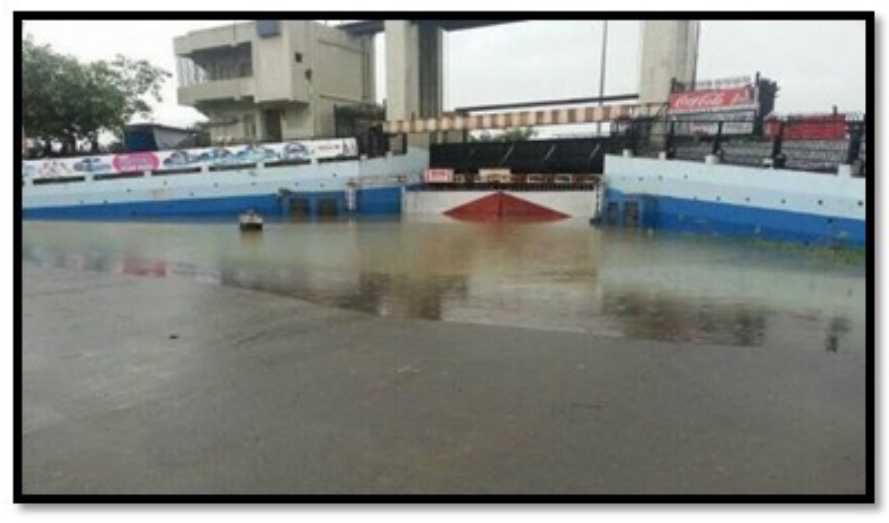

Fig. 4 Flood Level Increase

In the wake of the 2006 flood, the first task was improving coordination around management of the dam. Yagnik says the challenge is all the competing interests the dam serves. Flood control is only one of the dam's primary tasks. Others include providing irrigation water for agriculture and drinking water for people, as well as generating electricity.

The monsoon season is another complication. Most rain falls between the end of June and September, so some water hoarding is necessary to keep the reservoir full in the dry months. But when the planned release are necessary to avoid inundating areas downstream. "the big question was always about how much water to release and how much to store", said Yagnik.

The Surat Climate Change Trust became the venue for the various stakeholders to answer that and other question, both for long-term planning ahead of the rainy season and for emergency planning during a crisis. Rockefeller Foundation President Judith Rodin notes the importance of this structure for Surat in her recent book, "The resilience Dividend".

"Today, in contrast to 2006, the water management process involves decision makers at all levels," Rodin writes. "The involvements of private industry players is particularly important. If the lead-up to the 2006 scenario were to happen today, those business leader could, in a worst-case scenario, ask for intervention from the highest level of political and administrative authorities - and would not be ignored."

TARU Leading Edge Chairman, G.K. Bhatt said "Now that SCCT has leaned to handle forecasts, our role is to ensuring that there is buy-in and the forecasts are released daily." Indeed, heavy rains in 2013 gave the system a big test. It passed : There was water in Surat's streets, but not anywhere near as devastating as in 2006. "In 2013", Yagnik says, "we knew around when it was likely to rain heavily, how much water would be in the dam, the rise of the water level and how much water should be released."

\section{Results of Improving Coordination}

The other end of Surat's new early warning system is geared toward informing the public. In the past, vans fitted with loudspeakers belted out warning if flooding was imminent, asking residents with only a few hours to move higher ground with their valuables.

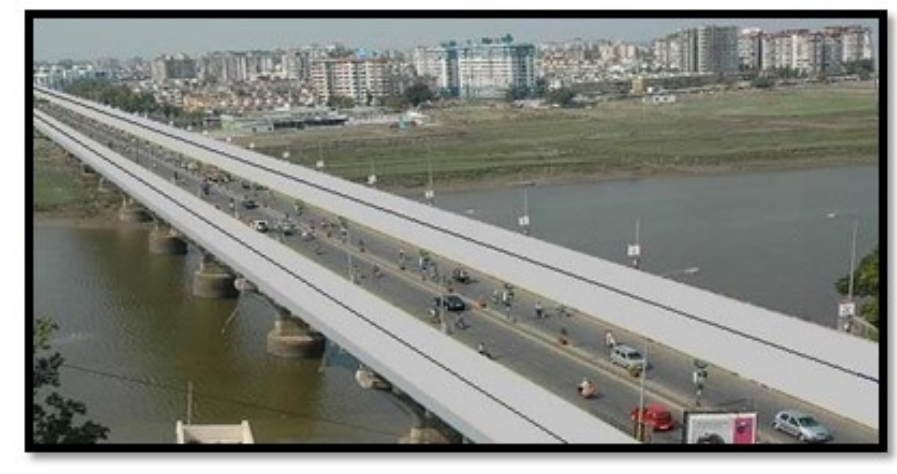

Fig 5: Height Increment.

Now, Whenever the Ukai reservoir capacity is raised by the height improvement from $270 \mathbf{f t}(\mathbf{1 9 9 8 )}, 345 \mathbf{f t}$ (2006), to $367 \mathrm{ft}$ (2017), a warning is sent to all citizens via SMS, 48 hours before any water is released. The Municipal Corporation has a smartphone application through which anyone can track the inflow and out flow of water at the Ukai reservoir. The Municipal Corporation also has strengthened its monsoon preparedness plan and sends out regular SMS alerts.

\section{Lessons Learned}

Whenever water level started increasing in Tapi River and entering into the city, SMC was not able to resist or stop it. However Government and other NonGovernmental Agencies and Local public helped each other in all possible ways. Then after the mismanagement in water releasing was found out as a main reason of flood occurrence. Then after SMC decided to increase the height of Ukai dam and implement the alarm system as a precautionary step. That alarm system will send warning system to the authorities and public through SMSs, so preparedness can be avail in time. Then flood rescue mock drills and trainings were also availed for local public safety purposes by government. People also initiated to learn 
precautionary steps, and rescue operation actions for the future flood. Infrastructural technologies also improved which can face the flood and have damages as lesser as possible.

\section{Conclusion}

As per this study of flood risk evaluation it is been come to know that when Surat is a victim city of many floods and when first major flood came in 1998 it damaged about half of the city area with flooding and then by taking some appropriate decisions and actions some improvements are done, but the another major flood came in 2006 which failed all the preparedness and majorly damaged the whole city. But then after also Surat Municipal Corporation made some actions which are now even stronger to face the higher flood also.

\section{REFERENCES}

1. RathDwarikanath, "The Manmade Flash Flood of Surat - Gujarat", Sabrang - Hate Hurts Harmony Works, $16^{\text {th }} \quad$ August 2006, https://sabrangindia.in/ann/man-made-flash-floodsurat-gujarat
2. ChetarjeePatralekha, "What Surat learned from a preventable flood", Citycope - Global Goals, Local Solutions, Surat, 3 September 2015, http://citiscope.org/story/2015/what-surat-learnedpreventable-flood

3. Bhatt Himanshu, "Ukai Dam Level Rising Rapidly", 2 August 2010, http://m.timesofindia.com/city/surat/Ukai-levelrising-rapidly/articleshow/6248722.cms

4. "Flood in Surat on September 2013", Maps of India, Last Modified, 23 September 2013, https://www.mapsofindia.com/surat/flood.html

5. G K Bhatt, Anup Karanth, Lalit Dashora, Umamaheshwaran Rajasekar "Addressing flooding in the city of Surat beyond its boundaries", Environment and Urbanization, Sage Journals Publications, Volume: 25 issue: 2, page(s): 429-441, 1 October 2013, http://journals.sagepub.com/doi/full/10.1177/0956 247813495002 